\title{
Peningkatan Kinerja Kelompok Usaha Pengolahan Ikan Air Tawar di Kabupaten Sleman
}

\author{
Wiwit Rahayu*, Sri Marwanti, Agustono, Minar Ferichani, Refa'ul Khairiyah dan Indah Nurhidayati \\ Program Studi Agribisnis, Fakultas Pertanian, Universitas Sebelas Maret, Surakarta, Indonesia
}

Diterima: 16 September 2020; Disetujui: 21 Oktober 2020

\begin{abstract}
Abstrak
Usaha budidaya ikan air tawar merupakan salah satu usaha yang banyak dilakukan oleh masyarakat Desa Sindumartani, Kecamatan Ngemplak, Kabupaten Sleman. Ketersediaan air dan lahan menjadikan sebagian besar masyarakat melakukan budidaya ikan air tawar terutama ikan nila. Hal ini menjadikan produk ikan melimpah. Kondisi ini memunculkan inisiatif ibu-ibu Kelompok Wanita Tani Mina Mandiri untuk mengolah hasil produksi ikan tersebut menjadi beberapa produk olahan ikan seperti keripik ikan dan abon. Salah satu kendala yang dihadapi dalam upaya mengembangkan usaha pengolahan ini adalah kinerja kelompok yang belum optimal karena kurangnya pengetahuan tentang kepentingan usaha secara berkelompok dan cara membuat kelompok yang solid dan kinerjanya baik. Pengabdian kepada masyarakat ini dilakukan dalam rangka memecahkan masalah tersebut dengan melakukan pelatihan dinamika kelompok meliputi teori dan praktik. Pelatihan dinamika kelompok yang dilakukan menjadikan ibu-ibu anggota Kelompok Wanita Tani Mina Mandiri memahami kepentingan usaha secara berkelompok, faktor-faktor yang menjadi kekuatan dan kelemahan kelompok dan kerja dalam kelompok (teamwork). Pemahaman dan keterampilan yang diperoleh dari kegiatan pengabdian menjadikan kinerja kelompok semakin meningkat. Hal ini dapat dilihat dari meningkatnya jumlah anggota yang hadir dalam rapat bulanan, bertambahnya frekuensi kegiatan produksi, bertambahnya jenis produk olahan ikan dan semakin luas wilayah pemasarannya.
\end{abstract}

Kata kunci: Kabupaten Sleman; kinerja kelompok; pengolahan ikan air tawar

\section{Performance Improvement of Freshwater Fish Processing Group in Sleman Regency}

\begin{abstract}
Freshwater fish farming is one of the efforts made by the people of Sindumartani Village, Ngemplak Sub-district, Sleman Regency. The battle for water and land has made most people cultivate freshwater fish, especially tilapia. This makes fish products abundant. This condition is the initiative of the Mina Mandiri Women Farmer Group to process the fish production into several processed fish products such as fish chips and shredded fish. One of the obstacles faced in the effort to develop this processing business is that the group's performance has not been optimal due to a lack of knowledge about group business interests and how to create a solid group with good performance. This community service is carried out in order to solve these problems by conducting group dynamics training both in theory and practice. The group dynamics training that was carried out made women members of the Mina Mandiri Women Farmer Group understand the importance of group business, the factors that are the strengths and weaknesses of groups and working in groups (teamwork). The understanding and skills obtained from community service activities increase the group's performance. This can be seen from the

\footnotetext{
* Corresponding author: wiwitrahayu@ staff.uns.ac.id
}

Cite this as: Rahayu, W., Marwanti, S., Agustono, Ferichani, M., Khairiyah, R., \& Nurhidayati, I. (2020). Peningkatan Kinerja Kelompok Usaha Pengolahan Ikan Air Tawar di Kabupaten Sleman. AgriHealth: Journal of Agri-food, Nutrition and Public Health, 1(2), 89-95. doi: http://dx.doi.org/10.20961/agrihealth.v1i2.44389
\end{abstract}


increasing number of members who attend monthly meetings, the increasing frequency of production activities, the increasing types of processed fish products and the wider the marketing area.

Keywords: freshwater fish processing; group performance; Sleman Regency

\section{PENDAHULUAN}

Perikanan budidaya (akuakultur) sangat potensial dalam meningkatkan pendapatan dan kesejahteraan rakyat, mampu menghasilkan pertumbuhan ekonomi tinggi (di atas $7 \%$ per tahun), inklusif (banyak menyerap tenaga kerja) dan berkelanjutan (Dahuri, 2016). Usaha budidaya ikan air tawar merupakan salah satu usaha yang banyak dilakukan oleh masyarakat Sindumartani, Kecamatan Ngemplak, Kabupaten Sleman. Ketersediaan air dan lahan yang memadai menjadikan sebagian besar masyarakat melakukan budidaya ikan air tawar terutama ikan nila. Hal ini menjadikan produksi ikan melimpah. Produksi ikan yang melimpah memunculkan inisiatif dari ibu-ibu anggota Kelompok Wanita Tani Mina Mandiri untuk mengolah hasil produksi ikan tersebut menjadi beberapa produk olahan seperti keripik ikan dan abon.

Usaha pengolahan ikan ini dimaksudkan untuk meningkatkan nilai tambah ikan sehingga akan meningkatkan pendapatan rumah tangga. Usaha pengolahan ikan dapat menjadi sumber off-farm income rumah tangga petani di Desa Sindumartani. Off-farm jobs berperan penting dalam mengurangi kemiskinan di pedesaan karena petani berskala kecil dapat meningkatkan pendapatan rumah tangga (De Janvry et al., 2005; Babatunde dan Qaim, 2009; Godoy dan Dewbre, 2010).

Usaha pengolahan ikan air tawar yang dilakukan oleh Kelompok Wanita Tani Mina Mandiri memiliki potensi untuk dikembangkan. Usaha ini memiliki omzet bulanan yang mencapai $\pm \mathrm{Rp}$ 3.000.000,00. Melimpahnya sumber bahan baku, lingkungan alam sekitar yang mendukung serta profil anggota kelompok yang tergolong terdidik, juga merupakan potensi yang mendukung pengembangan usaha pengolahan ikan air tawar ini.

Kelompok wanita tani merupakan organisasi sosial yang biasanya muncul karena adanya aktivitas, kepentingan dan tujuan yang sama. Organisasi sosial mencerminkan suatu pola tingkah laku yang terstruktur dalam setiap proses perubahan bentuk dan strukturnya. Organisasi sosial merupakan tempat yang memungkinkan bagi pengembangan aktivitas manusia dengan berbagai aturan yang diakui bersama. Anggota dalam organisasi sosial tersusun secara sistematis, setiap anggota mempunyai status dan peranan yang bersifat formal, masing-masing bertugas memelihara dan berusaha bersama untuk mencapai tujuan bersama (Abdulsyani, 2012).

Keberadaan Kelompok Wanita Tani Mina Mandiri diharapkan dapat mengembangkan usaha pengolahan ikan di Desa Sindumartani sehingga dapat meningkatkan kesejahteraan masyarakat. Salah satu kendala yang dihadapi dalam upaya mengembangkan usaha pengolahan ikan ini adalah kinerja kelompok yang belum optimal karena kurangnya pengetahuan tentang kepentingan usaha secara berkelompok dan cara membuat kelompok yang solid dan kinerjanya baik. Kondisi ini sering dialami oleh kelembagaan petani. Hasil penelitian Hermawan (2017) menunjukkan bahwa variabel dukungan kelompok berpengaruh negatif signifikan terhadap tingkat produktivitas usaha dan berpengaruh positif signifikan terhadap tingkat pendapatan pembudidaya ikan yang mengindikasikan harus adanya perbaikan manajemen kelembagaan kelompok pembudidaya ikan.

Kegiatan pengabdian kepada masyarakat ini diselenggarakan dalam rangka meningkatkan kinerja kelompok usaha pengolahan ikan air tawar yang dilakukan oleh Kelompok Wanita Tani Mina Mandiri. Kegiatan yang dilakukan adalah pelatihan dinamika kelompok mencakup teori dan praktik. Margolang (2018) menyatakan istilah dinamika kelompok berasal dari bahasa Inggris "dynamics" yang berarti mempunyai gairah atau semangat untuk bekerja. Dinamika kelompok juga merupakan suatu metode dan proses yang bertujuan meningkatkan nilai kerjasama kelompok. Artinya metode dan proses dinamika kelompok ini berusaha menumbuhkan dan membangun kelompok yang semula terdiri dari kumpulan individu yang belum saling mengenal satu sama lain menjadi satu kesatuan kelompok dengan satu tujuan, satu norma dan satu cara pencapaiannya yang disepakati bersama. 
Hunsaker (2001) dalam Ismara (2005) menyatakan bahwa salah satu faktor yang mendukung keberhasilan organisasi bisnis maupun nirlaba adalah dukungan tim kerja yang adaptif, fleksibel, cepat tanggap, solid dan pantang menyerah. Kegiatan pelatihan dinamika kelompok ini bertujuan untuk meningkatkan pengetahuan ibu-ibu anggota Kelompok Wanita Tani Mina Mandiri di Desa Sindumartani tentang kepentingan kerjasama dalam usaha, faktor-faktor yang menjadi kekuatan dan kelemahan kelompok dan kerja berkelompok. Hasil akhirnya diharapkan melalui pelatihan dinamika kelompok, kinerja Kelompok Wanita Tani Mina Mandiri meningkat sehingga usaha pengolahan ikan yang dilakukan dapat berkembang dan mampu meningkatkan pendapatan kelompok maupun anggota kelompok. Margolang (2018) mengatakan tujuan dinamika kelompok adalah (1) meningkatkan proses interaksi antara anggota kelompok; (2) meningkatkan produktivitas anggota kelompok; (3) mengembangkan kelompok ke arah yang lebih baik, lebih maju; (4) meningkatkan kesejahteraan hidup anggotanya.

\section{BAHAN DAN METODE}

\section{Tempat dan waktu pelaksanaan}

Kegiatan pengabdian dilaksanakan di Desa Sindumartani, Kecamatan Ngemplak, Kabupaten Sleman. Kegiatan ini melibatkan warga desa khususnya ibu-ibu yang tergabung dalam Kelompok Wanita Tani Mina Mandiri. Kegiatan dilaksanakan pada hari Senin tanggal 5 Agustus 2019 bertempat di rumah Ibu Sri Rejeki yang merupakan ketua Kelompok Wanita Tani Mina Mandiri.

\section{Jenis/rancangan kegiatan}

Kegiatan pengabdian ini menggunakan metode Participatory Rural Appraisal (PRA). $P R A$ adalah suatu metode yang menempatkan masyarakat sebagai subyek, perencana, pelaksana, sekaligus sebagai penilai dalam program pemberdayaan. Tim pengabdian dan stakeholder yang terlibat hanya sebagai fasilitator, sedangkan masyarakat merupakan pelaku utama. Pengabdian dilaksanakan setelah pencarian informasi mengenai masalah, kebutuhan dan potensi yang ada pada kelompok mitra pengabdian yaitu ibu-ibu anggota kelompok usaha pengolahan ikan pada Kelompok Wanita Tani Mina Mandiri.
Partisipasi dalam pengabdian ini didefinisikan sebagai gerakan masyarakat untuk terlibat dalam proses pembuatan keputusan, dalam pelaksanaan kegiatan, ikut menikmati hasil kegiatan dan ikut serta mengevaluasinya (Uphoff, 1988). Partisipasi berarti masyarakat terlibat dalam proses pendekatan "bottom-up" yang menuntut kemampuan berkomunikasi yang baik dan teknologi yang ditransfer dapat digunakan dalam situasi apapun (Cavestro, 2003). Mitra pengabdian dilibatkan dalam menentukan keputusan terkait dengan materi yang akan disampaikan dan berpartisipasi dengan membantu memberikan fasilitas tempat dan sarana pelatihan serta terlibat aktif dalam pelatihan dan implementasi hasil pelatihan.

\section{Metode serta langkah-langkah pelaksanaan}

Kegiatan pengabdian diawali dengan melakukan sosialisasi kegiatan kepada mitra dalam rangka memberitahukan adanya kegiatan pengabdian berupa pelatihan dinamika kelompok. Mitra menyambut baik adanya kegiatan pengabdian dan bersedia berpartisipasi aktif. Selanjutnya dilakukan koordinasi terkait dengan pelaksanaan kegiatan, tempat dan sarana prasarana yang diperlukan.

Kegiatan yang dilaksanakan dalam pengabdian ini adalah pelatihan dinamika kelompok untuk meningkatkan kinerja kelompok mitra. Pelatihan dinamika kelompok dilakukan dengan pemberian materi terkait dengan memahami kepentingan usaha secara berkelompok, faktor-faktor yang menjadi kekuatan dan kelemahan kelompok dan kerja dalam kelompok (teamwork). Pelatihan dilanjutkan dengan praktik pemecahan masalah dalam kerja berkelompok (teamwork). Narasumber pelatihan adalah Ibu Dr. Ir. Minar Ferichani, M.P.

\section{Evaluasi dan monitoring pelaksanaan kegiatan}

Evaluasi dan monitoring dilakukan selama kegiatan pelatihan dan evaluasi penerapan hasil pelatihan dalam menjalankan kegiatan kelompok. Evaluasi terkait dengan pemahaman materi dilakukan dengan memberikan pertanyaan kepada peserta pelatihan. Evaluasi ketrampilan dalam memecahkan permasalahan kelompok dilakukan dengan cara narasumber memberikan ulasan dari praktik yang dilakukan. Sedangkan evaluasi terhadap pelaksanaan materi pelatihan dilakukan dengan memonitoring kegiatan kelompok setelah dilakukan pelatihan. 


\section{HASIL DAN PEMBAHASAN}

\section{Pelatihan dinamika kelompok}

Pelatihan dinamika kelompok diikuti oleh 25 ibu-ibu anggota Kelompok Wanita Tani Mina Mandiri. Pelatihan diawali dengan pemberian materi dilanjutkan dengan diskusi dan praktik. Materi pelatihan yang disampaikan meliputi kepentingan usaha secara berkelompok, faktor-faktor yang menjadi kekuatan dan kelemahan kelompok dan kerja dalam kelompok (teamwork).

Penjelasan narasumber terkait dengan materi pelatihan adalah sebagai berikut:

1. Kepentingan usaha secara berkelompok

Narasumber menjelaskan bahwa sebagian besar orang lebih suka dan nyaman bekerja sendiri, padahal dalam pengembangan usaha perlu kerjasama dengan berbagai pihak. Pengembangan usaha seringkali terkendala apabila dilakukan sendiri karena daya tawar yang rendah ketika menghadapi kekurangan modal, konsumen maupun pesaing. Misalnya dalam usaha pengolahan ikan air tawar, salah satu masalah yang dihadapi adalah akses terhadap alat dan teknologi serta pemasaran. Keberadaan kelompok akan dapat mengatasi masalah tersebut karena dengan berkelompok modal akan menjadi lebih besar sehingga dapat mengakses alat dan teknologi dengan lebih mudah. Selain itu, keberadaan kelompok akan memudahkan pemasaran karena kapasitas dan kontinuitas produksi lebih terjaga sehingga mampu memenuhi kebutuhan konsumen yang mana hal ini sering menjadi masalah apabila usaha dilakukan secara sendiri. Usaha secara berkelompok juga akan meningkatkan daya tawar di hadapan konsumen dan mampu menghadapi persaingan pasar. Berdasarkan uraian tersebut disimpulkan bahwa keberadaan kelompok merupakan hal penting untuk mengembangkan usaha termasuk usaha pengolahan ikan air tawar yang dilakukan oleh Kelompok Wanita Tani Mina Mandiri.

2. Faktor yang menjadi kekuatan dan kelemahan kelompok

Kekuatan dan kelemahan kelompok bersumber dari lingkungan internal kelompok baik yang berkaitan dengan sumberdaya manusia, manajemen, keadaan keuangan maupun proses produksi. Kelompok yang kuat adalah kelompok yang memiliki visi dan tujuan yang jelas, inisiatif dan proaktif, berorientasi pada prestasi. Anggota kelompoknya berani mengambil risiko, kerja keras, bertanggungjawab terhadap segala aktifitas yang dijalankannya. Faktor yang juga menjadi kekuatan kelompok adalah hubungan baik dari ketua ke anggota, anggota ke ketua maupun pada sesama anggota. Narasumber menjelaskan bahwa kondisi sebaliknya dari hal-hal yang menjadi faktor kekuatan kelompok tersebut merupakan faktor yang menjadi kelemahan suatu kelompok.

3. Kerja dalam kelompok (teamwork)

Narasumber menjelaskan bahwa berkaitan dengan kinerja kelompok dalam menjalankan sebuah kelompok usaha bersama, sumberdaya manusia bisa menjadi kekuatan sekaligus menjadi kelemahan. Hal ini karena terdapat sifat-sifat spesifik yang perlu disadari oleh setiap anggotanya terutama terkait dengan sumberdaya manusia yang memiliki keunikan masing-masing dari sisi kreatifitas, karsa, kemampuan menjalankan usaha, kemandirian dan kemauan untuk belajar di dalam sebuah kelompok usaha. Pengetahuan tentang "teamwork" atau kerja tim perlu ditanamkan pada masing-masing anggota kelompok, sebab hal tersebut sangat mendasar untuk mencapai sasaran dan target atau goal yang konsisten dari sebuah usaha.

Kegiatan dilanjutkan dengan diskusi. Peserta pelatihan aktif bertanya terutama terkait dengan cara mengaktifkan anggota kelompok dalam setiap kegiatan, cara mengatasi masalah kerjasama, cara membangun keberanian untuk berpendapat dan cara mengembangkan pemasaran. Pertanyaan dijawab oleh narasumber dan diperkuat oleh anggota tim pengabdian yang lain. Kegiatan penyampaian materi pelatihan dan diskusi ditunjukkan pada Gambar 1.

Setelah pemberian materi dan diskusi, kegiatan dilanjutkan dengan praktik dinamika kelompok. Peserta pelatihan dalam kelompokkelompok kecil, kemudian diberikan persoalan untuk diselesaikan secara bersama-sama. Hasil dari penyelesaian masalah dipresentasikan oleh salah satu anggota kelompok. Kegiatan ini ditunjukkan oleh Gambar 2. Peserta pelatihan antusias mengikuti kegiatan yang ditunjukkan adanya partisipasi aktif dari peserta selama kegiatan pelatihan. Pelatihan diakhiri dengan foto bersama antara tim pengabdian dengan peserta pelatihan (Gambar 3). 


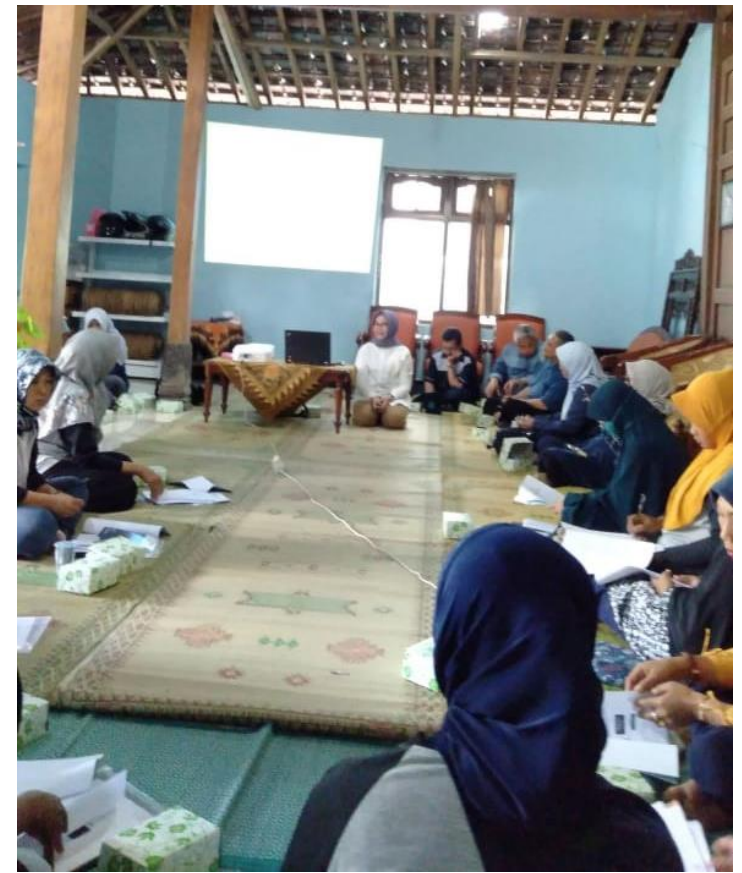

Gambar 1. Penyampaian materi oleh narasumber

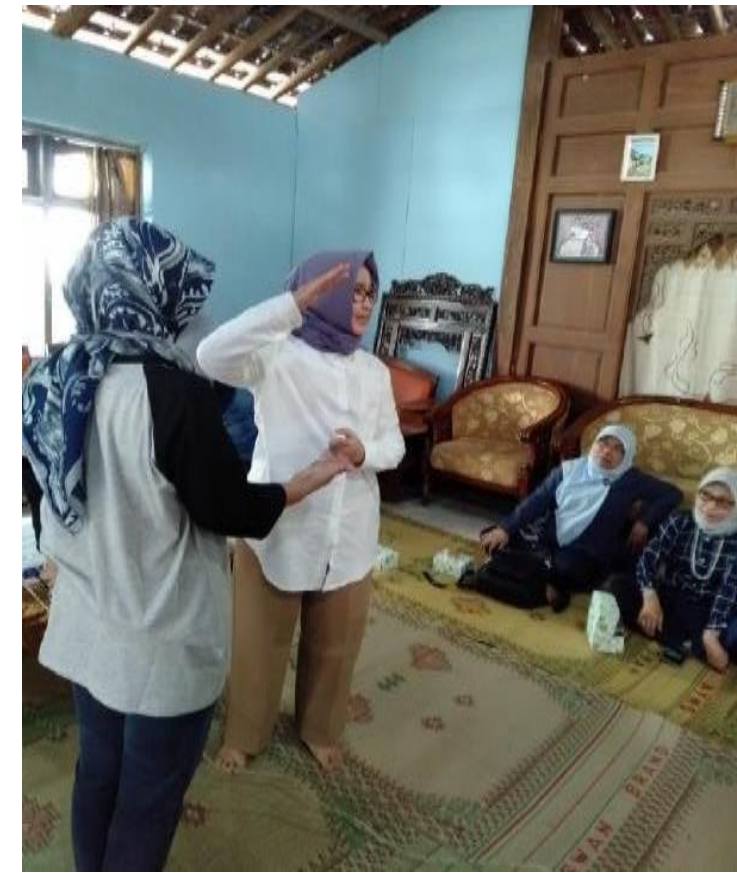

Gambar 2. Praktik dinamika kelompok

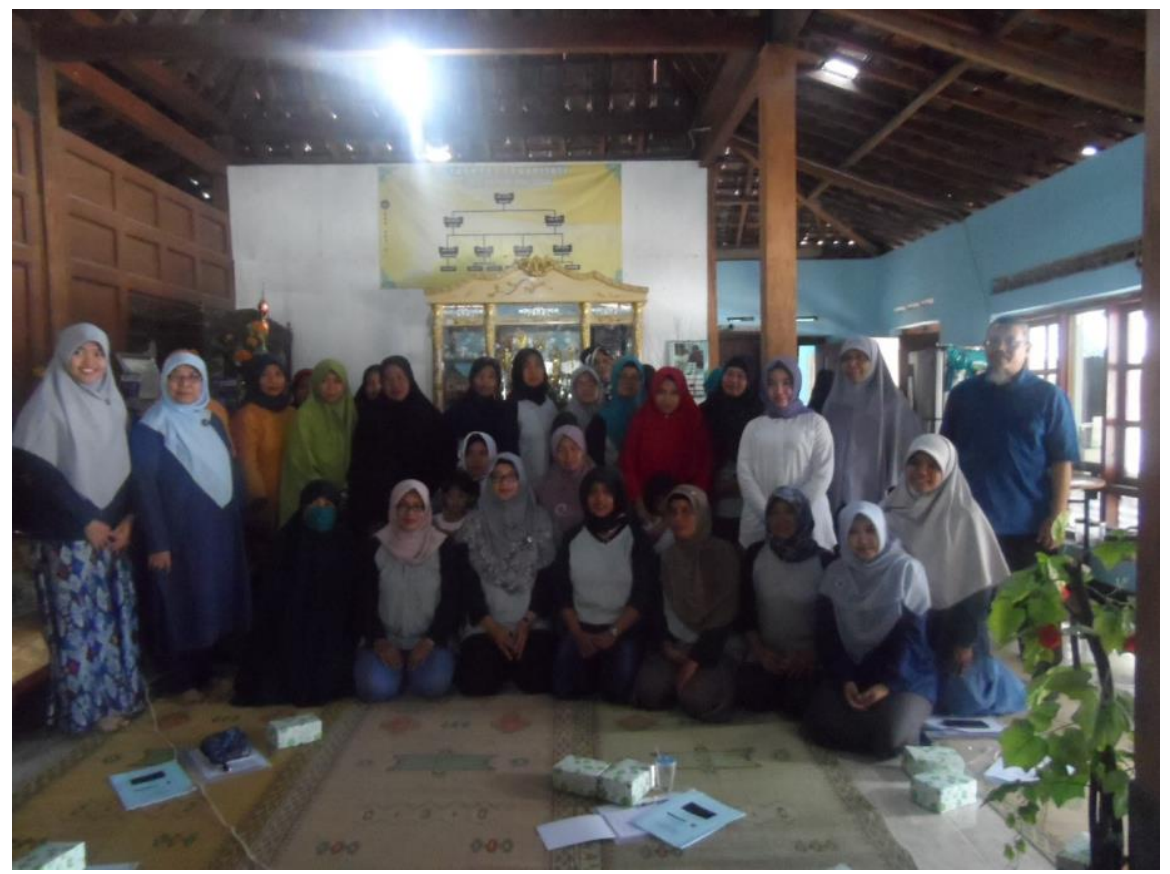

Gambar 3. Tim pengabdian dan peserta pelatihan kewirausahaan

Evaluasi dan monitoring pelaksanaan kegiatan

Evaluasi dan monitoring dilakukan untuk mengetahui implementasi pelatihan dan hasil yang dicapai. Hasil evaluasi dan monitoring menunjukkan bahwa dengan adanya pemberian materi tentang dinamika kelompok, maka ibu-ibu anggota Kelompok Wanita Tani Mina Mandiri memiliki pengetahuan tentang kepentingan adanya kelompok dalam menjalankan usaha pengolahan ikan, memahami faktor-faktor yang menjadi kekuatan dan kelemahan dalam kelompok dan kepentingan kerja berkelompok (teamwork). Peningkatan pengetahuan setelah adanya penyuluhan juga terjadi pada kegiatan pengabdian tentang pembuatan pupuk organik yaitu adanya peningkatan pengetahuan sebesar 12,50 dari rata-rata pengetahuan awal sebesar 
59,88 menjadi 72,38 setelah mengikuti kegiatan penyuluhan dan pelatihan (Emawati et al., 2020).

Hasil monitoring dan evaluasi juga menunjukkan adanya peningkatan kinerja Kelompok Wanita Tani Mina Mandiri dalam menjalankan kelompok usaha pengolahan ikan. Hal ini dapat dilihat dari meningkatnya jumlah anggota yang hadir dalam rapat bulanan (semua anggota hadir dalam rapat, jika ada yang tidak hadir karena ada keperluan lain), bertambahnya frekuensi kegiatan produksi seminggu 2 kali menjadi seminggu 3-4 kali produksi dan bertambahnya jenis produk olahan ikan yaitu bakso dan nugget ikan. Wilayah pemasaran juga semakin luas, tidak hanya dipasarkan di outlet yang ada di kelompok, tetapi juga dipasarkan ke luar desa.

\section{KESIMPULAN}

Kegiatan pengabdian ini telah dapat mencapi tujuannya yaitu meningkatkan kinerja Kelompok Wanita Tani Mina Mandiri dalam menjalankan usaha pengolahan ikan air tawar. Kegiatan pengabdian masyarakat telah berjalan dengan lancar karena adanya kerjasama antara tim pengabdian dan mitra. Pemahaman dan keterampilan yang diperoleh dari kegiatan pengabdian menjadikan kinerja kelompok semakin meningkat. Hal ini dapat dilihat dari meningkatnya jumlah anggota yang hadir dalam rapat bulanan, bertambahnya frekuensi kegiatan produksi, bertambahnya jenis produk olahan ikan dan semakin luas wilayah pemasarannya.

\section{UCAPAN TERIMA KASIH}

Tim pengabdian menyampaikan terima kasih yang sebesar-besarnya kepada Kelompok Wanita Tani Mina Mandiri yang telah berpartisipasi aktif dalam mengikuti kegiatan dan mendukung kegiatan dengan menyediakan tempat dan sarana lain yang diperlukan sehingga kegiatan dapat berjalan lancar.

\section{DAFTAR PUSTAKA}

Abdulsyani. (2012). Social sistematika, teori dan terapan. Jakarta: Bumi Aksara.

Babatunde, R. O., \& Qaim, M. (2009). The role of off-farm income diversification in rural Nigeria: Driving forces and household access. CSAE conference on economic development in Africa, St Catherine's College, Oxford, pp. 1-26. Tersedia dari http://citeseerx.ist.psu.edu/ viewdoc/download?doi=10.1.1.410.5659\&rep $=$ rep $1 \&$ type $=$ pdf

Cavestro, L. (2003). P.R.A. - Participatory rural appraisal concepts methodologies and techniques. Padova University. Padova PD. Italia. Tersedia dari https://static1.squarespa ce.com/static/5eb18d627d53aa0e85b60c65/t/ 5f00bb7247a3f5734827af16/1593883507248/ PARTICIPATORY-RURAL-APPRAISAL. pdf

Dahuri, R. (2016). Akuakultur: Raksasa ekonomi Indonesia yang tertidur. Republika. Tersedia dari https://republika.co.id/berita/jurnalismewarga/wacana/16/08/01/ob7ksr336-akuakultu r-raksasa-ekonomi-indonesia-yang-tertidur

De Janvry, A., Sadoulet, E., \& Zhu, N. (2005). The role of non-farm income in reducing rural poverty and inequality in China,. Department of Agricultural \& Resource Economics, UC Berkeley, Working Paper No. 1001. Tersedia dari https://econpapers.repec.org/paper/arecud are/1001.htm

Emawati, S., Rahayu, E. T., Suwarto, S., \& Sudiyono, S. (2020). Pemberdayaan peternak dalam teknologi produksi pupuk organik dan biogas di Desa Gedong dan Desa Gemawang Kecamatan Ngadirojo, Kabupaten Wonogiri. AgriHealth: Journal of Agri-food, Nutrition and Public Health, 1(1), 14-21. https://doi. org/10.20961/agrihealth.v1i1.40449

Godoy, D. C., \& Dewbre, J. (2010). Economic importance of agriculture for sustainable development and poverty reduction: findings from a case study of Indonesia. Global Forum on Agriculture 29-30, November 2010, Policies for Agricultural Development, Poverty Reduction and Food Security OECD Headquarters, Paris. Tersedia dari https://www .researchgate.net/publication/236607686_Eco nomic_Importance_of_Agriculture_for_Susta inable_Development_and_Poverty_Reduction _Findings_from_a_Case_Study_of_Ghana

Hermawan, A. (2017). Kapasitas dan kinerja pengelolaan usaha akuakultur anggota kelompok pembudidaya ikan di Kabupaten Tasikmalaya. Jurnal Penyuluhan Perikanan dan Kelautan, 11(3), 160-176. https://doi.org/ 


\subsection{8/jppik.v11i3.93}

Hunsaker, P. L. (2001). Training in Managment Skill. New Jersey: Pretince-Hall.

Ismara, K. I. (2005). Out ward bound game salah satu metode dinamika kelompok dalam pengembangan sumberdaya manusia. Indogenous. Jurnal Berkala ilmiah Psikologi, 1(3), 85-94. Tersedia dari http://journals.ums. ac.id/index.php/indigenous/article/view/4635
Margolang, N. (2018). Dinamika Kelompok [Modul Pelatihan Dasar Fungsional Bagi Penyuluh Pertanian Terampil Angkatan XI 2018]. Tersedia dari http://pelatihan.distphbun .riau.go.id/files/Dinamika\%20Peserta\%20Ter ampil.pdf

Uphoff, N. (1988). "Menyesuaikan Proyek pada Manusia" dalam Mengutamakan Manusia di dalam Pembangunan. Jakarta: Universitas Indonesia Press 